\title{
Designing B2C Honey Bee E-Commerce System using Object Oriented Method
}

\author{
$1^{\text {st }}$ Achmad Tjachja Nugraha ${ }^{1}, 2^{\text {nd }}$ Elpawati $^{1}, 3^{\text {rd }}$ Puspi Eko Wiranthi $^{2}, 4^{\text {th }}$ Nida'ul Hasanati $^{1}$ \\ \{achmadtjahja@uinjkt.ac.id1, elpawati@uinjkt.ac.id,nidaul.hasanati@uinjkt.ac.id, \\ puspiew@uinjkt.ac.id\}
}

UIN Syarif Hidayatullah, Department of Agribusiness, Jakarta, Indonesia ${ }^{1}$, UIN Syarif Hidayatullah, Department of Informatics, Jakarta, Indonesia ${ }^{2}$

\begin{abstract}
Honey is a natural product produced by bees, both sting bees and stingless bees. Both types of bees produce honey which is very beneficial for human health. Honey bee cultivation has been widely practiced in Indonesia. The need for honey annually increases both in Indonesia and in the world, but the marketing of honey products is still very simple, mostly using traditional trade. So, the utilization and improvement in the IT field is something very necessary in order market these products so that people can quickly feel the benefits. The purpose of this research is to develop Business to Costumer (B2C) e-commerce system, which introduces the benefits and products of bees (containing honey, propolis and bee pollen) and online sales. The research method consists of collecting data with interviews and literature studies; and developing system with the Rapid Application System Development (RAD) method, using object-oriented analysis and design techniques and the Unified Modeling Language (UML) as a tool. The results of this study are the establishment of an e-commerce system, that can manage product, customer, and sales data and also provide reports, as well as reduce risks in the transaction process.
\end{abstract}

Keywords: e-commerce, b2c, honey bee, object oriented analysis and design, rapid application development, uml

\section{Introduction}

In the current era of globalization, free trade and privatization, information technology plays an important role in terms of producing something competitive. With the existence of a global market and through all the parts covered by IT such as email, multimedia, electronic banking, internet and so on. With the existence of IT, we can use it in any case. One of them is using IT in terms of sales. Sales made using IT are certainly easier to do in terms of selling or buying. We can sell or buy items we want by using IT.

E-Commerce is one of the developments of IT in terms of business activities involving consumers (consumers), manufactures, service providers and intermediaries by using computer networks (internet networks), so that they can make it easier for consumers or customers who will buy accessories so they can access via the internet and online.

Definition of E-Commerce itself, namely as one of the dynamic sets of technology, applications, and business processes that connect certain companies, consumers and communities through electronic transactions and trade in goods, services, and information 
carried out electronically [1]. It can be concluded that E-Commerce means to buy or sell electronically that is done on the internet network. E-Commerce looks more real, with the need for sellers and buyers to make transactions.

Bees are God's creatures that produce honey. Many properties are produced by honey and God commands us to be able to use honey as a medicine. Honey is a natural product produced by stinging bees and stingless bees. Both types of bees produce honey with specific phenolic and flavonoid content which is very beneficial for human health [2].

Honey bee cultivation has been widely practiced in Indonesia. The need for honey annually increases both in Indonesia and in the world, but the marketing of honey products is still very simple, mostly using traditional trade. So, the utilization and improvement in the IT field is something very necessary in order market these products so that people can quickly feel the benefits . The purpose of this research is to develop Business to Costumer (B2C) ecommerce system, which introduces the benefits and products of bees (containing honey, propolis and bee pollen) and online sales.

\section{Literature Review}

The bee that is currently booming is cultivated is Trigona Stingless Bee. The bee is a stingless bee that is not dangerous and can be cultivated anywhere, both in large gardens and in the land around the house. Trigona cultivation allows for those who do not have large land. Trigona is the largest genus of bees without sting. Trigona is in the Neotropic region and also throughout the Indo-Australian region. There are about 150 species that belong to this genus, which distinguishes mainly from the hind legs. The Trigona Stingless Bee classification is as follows:

$\begin{array}{ll}\text { Kingdom: } & \underline{\text { Animalia }} \\ \text { Phylum: } & \underline{\text { Arthropoda }} \\ \text { Class: } & \underline{\text { Insecta }} \\ \text { Order: } & \underline{\text { Hymenoptera }} \\ \text { Superfamily: } & \underline{\text { Apoidea }} \\ \text { Family: } & \underline{\text { Apidae }} \\ \text { Subfamily: } & \underline{\text { Apinae }} \\ \text { Tribe: } & \underline{\text { Meliponini }} \\ \text { Genus: } & \text { Trigona }\end{array}$

Jurine, 1807

Stingless bee bees besides producing honey and propolis also have other benefits, namely as a pollinator. Stingless bees can become pollinators better than honeybee pollinators. Trigona SP stingless Bee can grow and develop around the house (yard, on house terraces, under the roofs of houses protected from rain. Trigona SP bee cultivation is much easier 
compared to Avis Mallivera (stinging bees) because it must be done with a system of angon (migratory beekeeping), that is bees grazed in a mobile manner following the flower season of plants [4].

These are the two options for electronic trading (electronic commerce or e-commerce): Business-to-Consumer (B2C) and business-to-business (B2B). Business-to-consumer, is a process for selling products directly to consumers. B2B, which stands for business-tobusiness, is a process for selling products or services to other businesses. [12].

\section{Research Method}

This research method begins with literature study, by collecting literatures, papers, and books from prior studies that discuss about Bee, especially for the Stingless Bee, and materials about e-business and e-commerce. The next step is interviews, that asking questions to the interviewees about the process of Stingless Bee cultivation and the honey production. The next step is observation. Observation is carried out the direct observations of the trigona bee cultivation process at the Compost House of UIN Jakarta. The results obtained are bee trigona culture can produce honey propolis and bee pollen. The last step, is document review, that is collecting data by tracing and recording relevant data, like form or report documents, archives, and references at the UIN Jakarta Compost House.

For developing this e-commerce system, System development method used is the Rapid Application Development (RAD) development model [kendal]. There are three phases in RAD that involve : 1) Requirements planning phase, This phase is carried out to identify the purpose of the application or system and to identify the information requirements that arise from this goal. Orientation in this phase is solving company problems, that align with company's goals. 2) RAD design Workshop phase, This phase is to design and improve which can be described as a workshop. Analysts and programmers can work to build and demonstrate visual representations of design and work patterns to users. System Analysis and Design method that used in this study are Object Oriented Analysis and Design (OOAD) using UML tool. Process design which consists of identifying actors, identifying proposed system use cases and designing proposed system use case diagrams, database design, and interface Design. In this phase also produces a system prototype designed and improved based on user responses. If the developer is an experienced developer or user, Kendall believes that this creative effort can drive development to an accelerated level. 3) Implementation. During this implementation phase, analysts work with users intensely during workshops and design business and nontechnical aspects of the company. As soon as these aspects are approved and systems are built and filtered, new systems or parts of the system are tested and then introduced to the organization. 


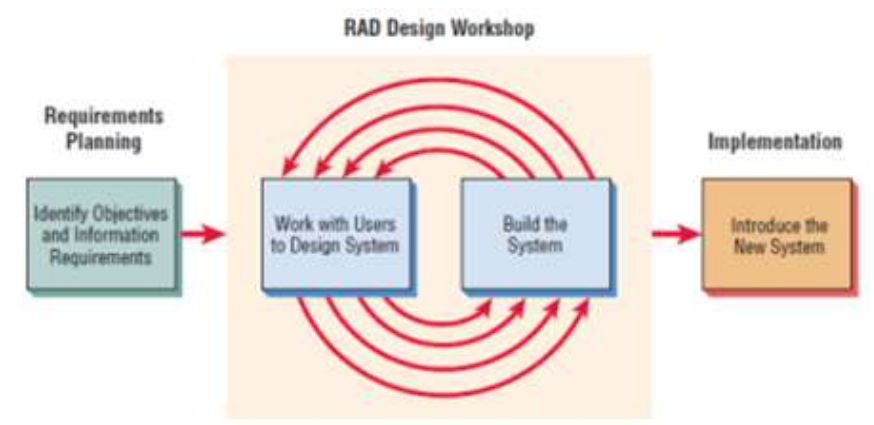

Figure 1. RAD

\section{Result}

Bees are special creatures, created by God Almighty that provide health benefits and enjoyments to humans. so that the activity of bee cultivation is a beneficial activity for human life. This is related to the implementation of trigona bee cultivation at the composting house of UIN Jakarta.

The results of the benefits of trigona bee production which produce honey, propolis and bee pollen provide business opportunities for cultivation. The productivity of bee trigona products at Kompos UIN House is the amount of honey, propolis and bee pollen produced in one year

Table 1. Results of Tabulation of Trigona Beekeeping Production Results per Year

\begin{tabular}{|l|l|l|l|}
\hline \multicolumn{1}{|c|}{ Product Type } & \multicolumn{1}{|c|}{$\begin{array}{c}\text { Production } \\
\text { Results }\end{array}$} & \multicolumn{1}{c|}{$\begin{array}{c}\text { Unit of } \\
\text { Production }\end{array}$} & \multicolumn{1}{|c|}{ Number per Bottle } \\
\hline Bee & $15.068 \mathrm{~mL}$ & $250 \mathrm{~mL}$ & 60 \\
\hline Propolis & 27.189 gram & 250 gram & 109 \\
\hline Bee Pollen & 6.956 gram & 250 gram & 28 \\
\hline Total & & $\mathbf{1 9 7}$ \\
\hline
\end{tabular}

Resource: Elpawati \& Wahyu Rochman, 2017

Details of honey bee trigona products amounted to $15,068 \mathrm{~mL}$ or 60 bottles of 250 $\mathrm{mL}$ with selling price in the domestic market averaging $\mathrm{Rp} .150,000$, - and generate revenue of Rp. 9,000,000, - propolis products amounted to 27,189 grams or 109 bottles of 250 grams per bottle and the selling price in the domestic market is averaged Rp. 250,000, - and generate revenue of Rp. $27,250,000$, - while the product amounted bee pollen to 6,956 grams or 28 
bottles of 250 grams with a selling price of Rp. 100,000, - and generate revenue of Rp. $2,800,000$.

The largest amount of production produced by Bee Trigona at the Composite House of UIN Jakarta is the production of propolis compared to the production of honey and bee pollen. This is due to the lack of flower feed which produces nectar and pollen in the cultivation area. While foreign market participants benefit from the production of Bee trigona which produces honey and propolis, it provides business opportunities at this time, the wholesale market price of honey and propolis is around AU \$ 50 per kg in Asia, the stingless beekeeping for pollination is only beginning to take root in Asia South, India and in Southeast Asia including Malaysia and the Philippines [14].

\subsection{System Comparative Analysis}

Based on the proposed e-commerce system design, the comparison of the system running with the proposed system is shown in Table 2 as follows:

Table 2. Comparison of Current Systems and Proposed Systems

\begin{tabular}{|l|l|}
\hline Current System & Proposed System \\
\hline $\begin{array}{l}\text { The process of inputting } \\
\text { orders is still via email or } \\
\text { telephone by the consumer } \\
\text { and recorded in Microsoft } \\
\begin{array}{l}\text { Excel by the sales } \\
\text { department. }\end{array}\end{array}$ & $\begin{array}{l}\text { The process of inputting } \\
\text { orders bas been automated } \\
\text { stored directly in the } \\
\text { database. System will } \\
\text { automatically update stock, } \\
\text { and produce invoice/billing } \\
\text { transaction }\end{array}$ \\
\hline $\begin{array}{l}\text { Verification and validation } \\
\text { of orders and stock } \\
\text { checking still manually } \\
\text { checks the stock file. }\end{array}$ & $\begin{array}{l}\text { Order verification and } \\
\text { validation are automated by } \\
\text { displaying the latest stock } \\
\text { of the items ordered. }\end{array}$ \\
\hline $\begin{array}{l}\text { Distribution route creation } \\
\text { is still manual by the } \\
\text { distribution department. }\end{array}$ & $\begin{array}{l}\text { Making automated routes } \\
\text { using certain formulas. }\end{array}$ \\
\hline $\begin{array}{l}\text { Making manual shipping } \\
\text { and sales reports refers to } \\
\text { order data. }\end{array}$ & $\begin{array}{l}\text { Making automated shipping } \\
\text { and sales reports on the } \\
\text { system according to the data } \\
\text { stored in the database. }\end{array}$ \\
\hline $\begin{array}{l}\text { Making manual shipping } \\
\text { and sales reports refers to } \\
\text { order data. }\end{array}$ & \\
\hline
\end{tabular}

\subsection{Identification of Actors}

Actors involved in this e-commerce system are grouped into 5 actors, namely Admin, Customer, Sales Division, Distribution Division and Executive. A clearer definition of the description of the roles of these actors can be seen in Table III regarding the identification of actors. 
Table 3. Identification of Proposed System Actors

\begin{tabular}{|l|l|l|}
\hline No. & Aktor & Deskripsi \\
\hline 1. & Admin & $\begin{array}{l}\text { Admin is an actor who can manage } \\
\text { accounts (create, change, and delete) on } \\
\text { the system. }\end{array}$ \\
\hline 2. & Customer & $\begin{array}{l}\text { Customer is an actor who can input } \\
\text { orders, which refers to a person who buys } \\
\text { the goods or commodity and pays the } \\
\text { price for it. Customer can be a consumer, } \\
\text { the one who consumes the goods. }\end{array}$ \\
\hline 3. & Sales Division & $\begin{array}{l}\text { The Sales Division is an actor whose role } \\
\text { is to verify and validate orders and make } \\
\text { sales invoices. }\end{array}$ \\
\hline 4. & $\begin{array}{l}\text { Distribution } \\
\text { Division }\end{array}$ & $\begin{array}{l}\text { The Distribution Division is an actor who } \\
\text { can check incoming orders, make routes } \\
\text { for distribution and make travel } \\
\text { documents. }\end{array}$ \\
\hline 5. & Executives & $\begin{array}{l}\text { Executives are executive level actors who } \\
\text { can view shipping reports and sales } \\
\text { reports }\end{array}$ \\
\hline
\end{tabular}

\subsection{Identification of Use Case}

Table 4 shows the interaction between actors with the proposed system which will be expressed in the form of use case identification tables. Use case is description of system functions from the perspective of external users in terminology they understand.

The system consists of several functions, there are login, order input, create an invoice, order verification and validation, manage user, view order, create distribution route, create shipping documents, view sales report, view delivery report, logout function.

Table 4. Identification of Use Case Proposed Systems

\begin{tabular}{|l|l|l|l|}
\hline No. & $\begin{array}{l}\text { Use Case } \\
\text { Name }\end{array}$ & Description & Actor \\
\hline 1. & Login & $\begin{array}{l}\text { Use case ini } \\
\text { menggambarkan } \\
\text { proses aktor masuk } \\
\text { ke dalam sistem. }\end{array}$ & $\begin{array}{l}\text { Admin, } \\
\text { Division, } \\
\text { Distribution } \\
\text { Division, Customer, } \\
\text { and Executive }\end{array}$ \\
\hline 2. & Order Input & $\begin{array}{l}\text { This use case } \\
\text { describes the actor's } \\
\text { process in making } \\
\text { an order, and } \\
\text { system will update } \\
\text { stock automatically }\end{array}$ & Customer \\
\hline 3. & $\begin{array}{l}\text { Order } \\
\text { Verification } \\
\text { and } \\
\text { Validation }\end{array}$ & $\begin{array}{l}\text { This use case } \\
\text { describes the actor's } \\
\text { process of verifying } \\
\text { and validating } \\
\text { incoming orders. }\end{array}$ & \\
\hline
\end{tabular}




\begin{tabular}{|c|c|c|c|}
\hline 4. & $\begin{array}{l}\text { Manage } \\
\text { Users }\end{array}$ & $\begin{array}{l}\text { This use case } \\
\text { describes the actor's } \\
\text { process of } \\
\text { managing (creating, } \\
\text { changing and } \\
\text { deleting) user } \\
\text { accounts in the e- } \\
\text { commerce system }\end{array}$ & Admin \\
\hline 5. & View Order & $\begin{array}{l}\text { This use case } \\
\text { describes the actor's } \\
\text { process in checking } \\
\text { orders to prepare } \\
\text { product shipments }\end{array}$ & $\begin{array}{l}\text { Distribution } \\
\text { Division }\end{array}$ \\
\hline 6. & $\begin{array}{l}\text { Create } \\
\text { Distribution } \\
\text { Route }\end{array}$ & $\begin{array}{l}\text { This use case } \\
\text { describes the actor's } \\
\text { process in making } \\
\text { the right order } \\
\text { distribution route. }\end{array}$ & $\begin{array}{l}\text { Distribution } \\
\text { Division }\end{array}$ \\
\hline 7. & $\begin{array}{l}\text { Create } \\
\text { shipping } \\
\text { documents }\end{array}$ & $\begin{array}{l}\text { This use case } \\
\text { describes the actor's } \\
\text { process in preparing } \\
\text { shipping documents }\end{array}$ & $\begin{array}{l}\text { Distribution } \\
\text { Division }\end{array}$ \\
\hline 8. & $\begin{array}{ll}\text { Create } & \text { an } \\
\text { Invoice } & \end{array}$ & $\begin{array}{l}\text { This use case } \\
\text { describes creating } \\
\text { invoice } \\
\text { automatically to } \\
\text { customer }\end{array}$ & Sales Division \\
\hline 9. & $\begin{array}{l}\text { View } \\
\text { delivery } \\
\text { report }\end{array}$ & $\begin{array}{l}\text { This use case } \\
\text { describes the actor's } \\
\text { process in creating } \\
\text { and viewing } \\
\text { delivery reports }\end{array}$ & Executive \\
\hline 10. & $\begin{array}{ll}\text { View } & \text { sales } \\
\text { report } & \end{array}$ & $\begin{array}{l}\text { This use case } \\
\text { describes the actor's } \\
\text { process in creating } \\
\text { and viewing sales } \\
\text { reports. }\end{array}$ & Executive \\
\hline 11. & Logout & $\begin{array}{l}\text { This use case } \\
\text { describes the } \\
\text { process of the actor } \\
\text { coming out of the } \\
\text { system. }\end{array}$ & $\begin{array}{l}\text { Admin, Sales } \\
\text { Division, } \\
\text { Distribution } \\
\text { Division, Customer, } \\
\text { and Executive }\end{array}$ \\
\hline
\end{tabular}

\subsection{Design of Proposed System Use Case}

The interaction between actors with the system which will be expressed in the form of use case diagram, shown in Figure 2. It shows the interaction between actors with the B2C system. 


\subsection{Design of Proposed System Database Scheme}

In Figure 3 is a relational database scheme for the proposed $\mathrm{B} 2 \mathrm{C}$ e-commerce system. This is the result of mapping from the class diagram, which shows data collection in systems that are interrelated with each other and organized in the system to run processes that exist in the e-commerce system.

\subsection{Design of User Interface}

Figure 4, 5, and 6 show the examples of user interfaces of the e-commerce system. There are home interface of the e-commerce website, interface of product profiles and benefits, order and billing transaction interface.

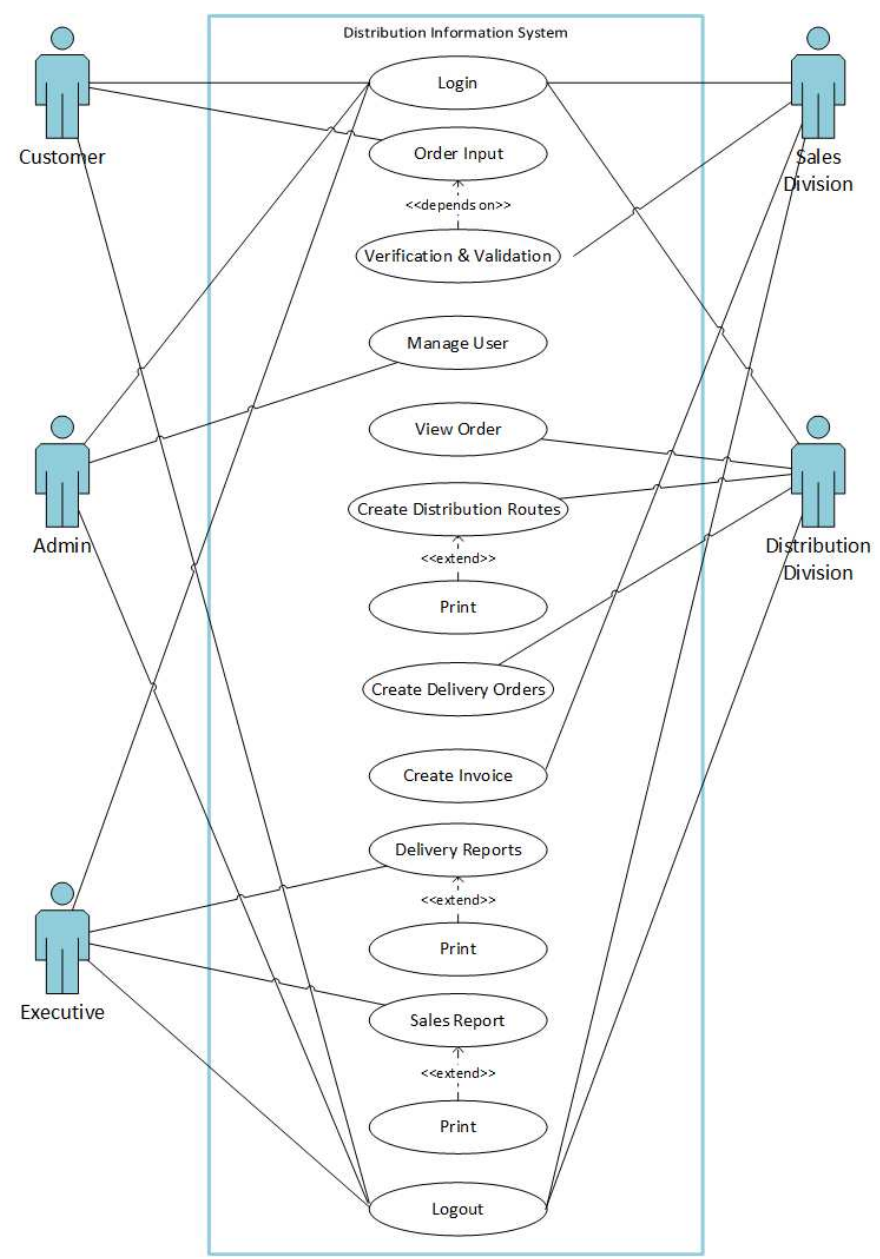

Figure 2. Design of Proposed System Use Case 


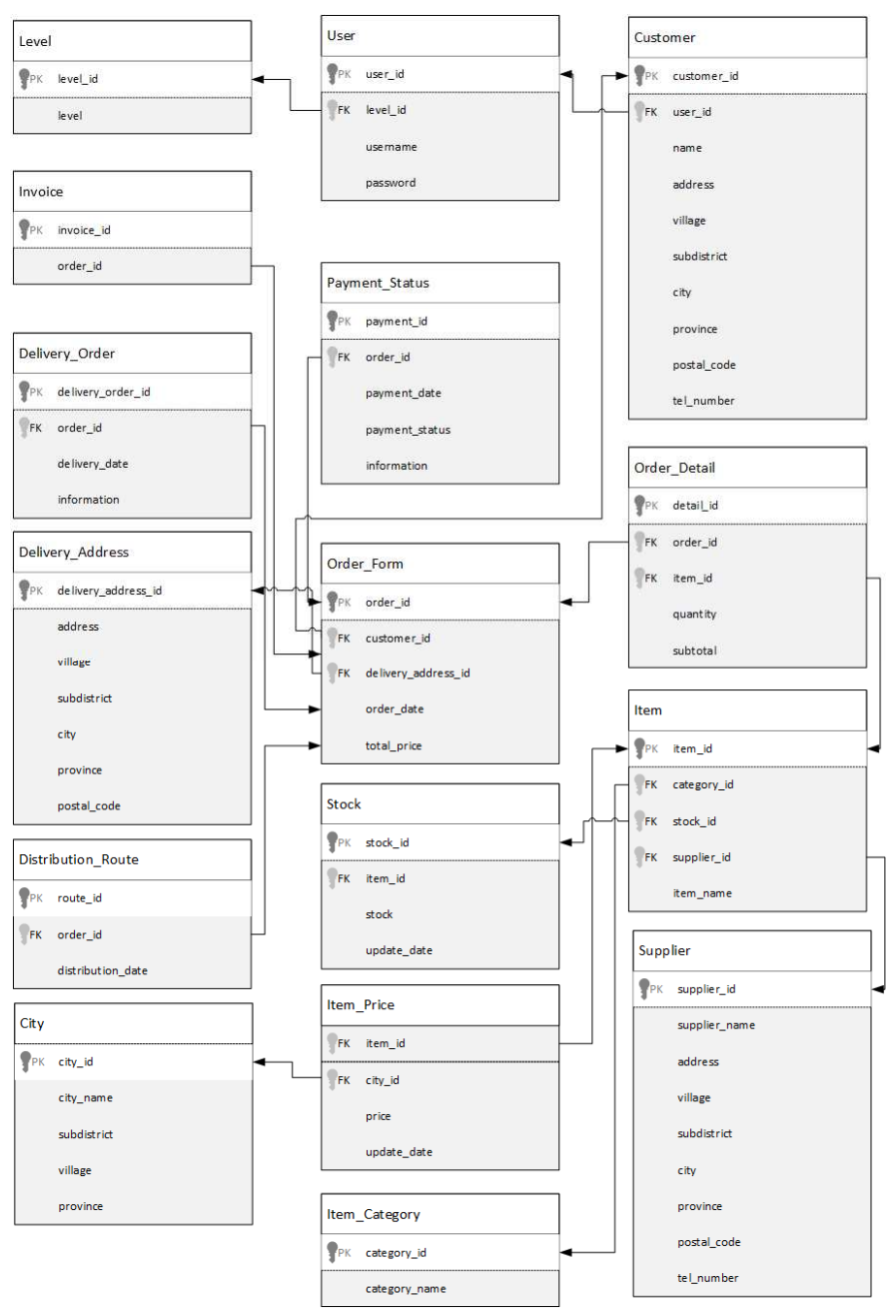

Figure 3. Proposed System Database Scheme 


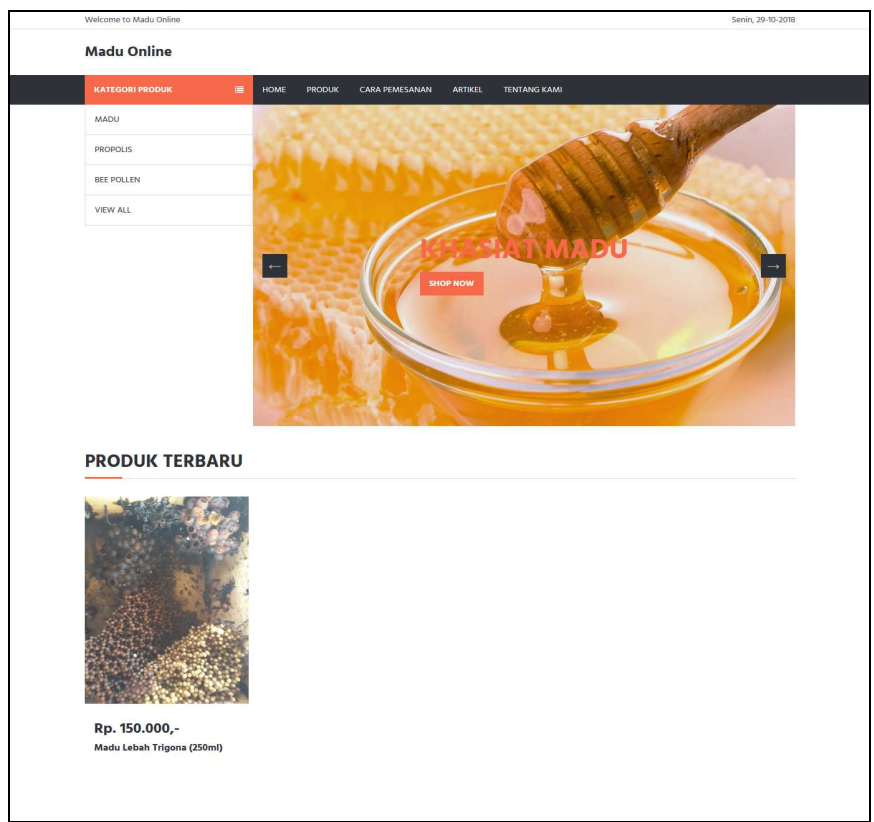

Figure 4. Home Interface of The E-Commerce Website

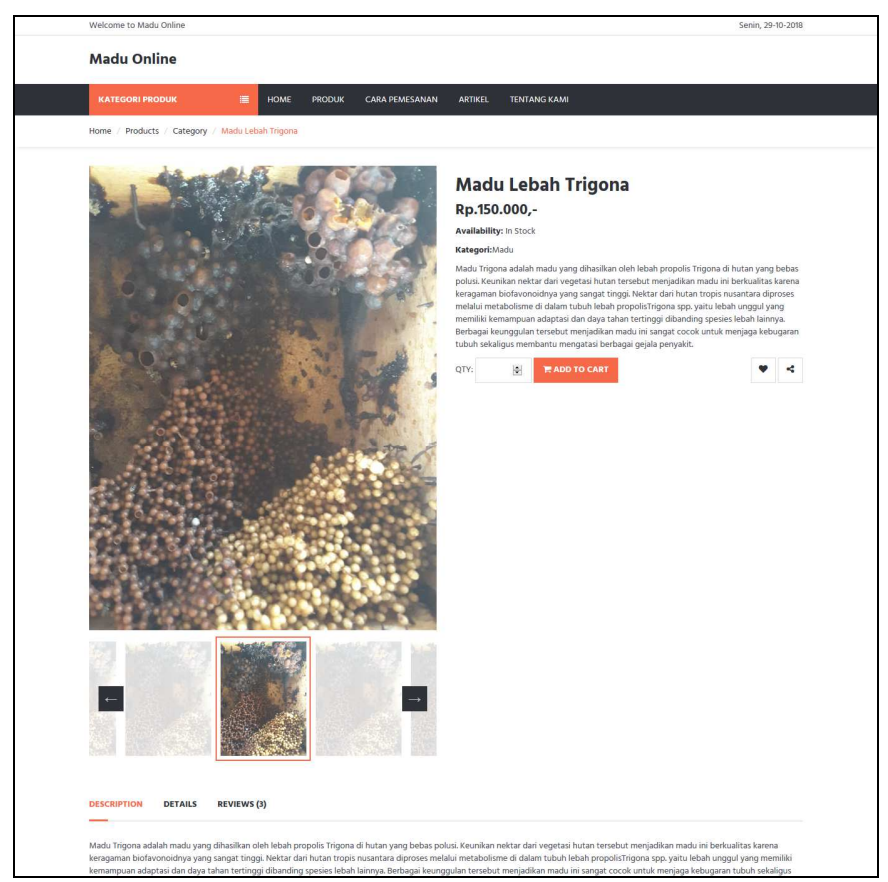

Figure 5. Interface of Product Profiles and Benefits 


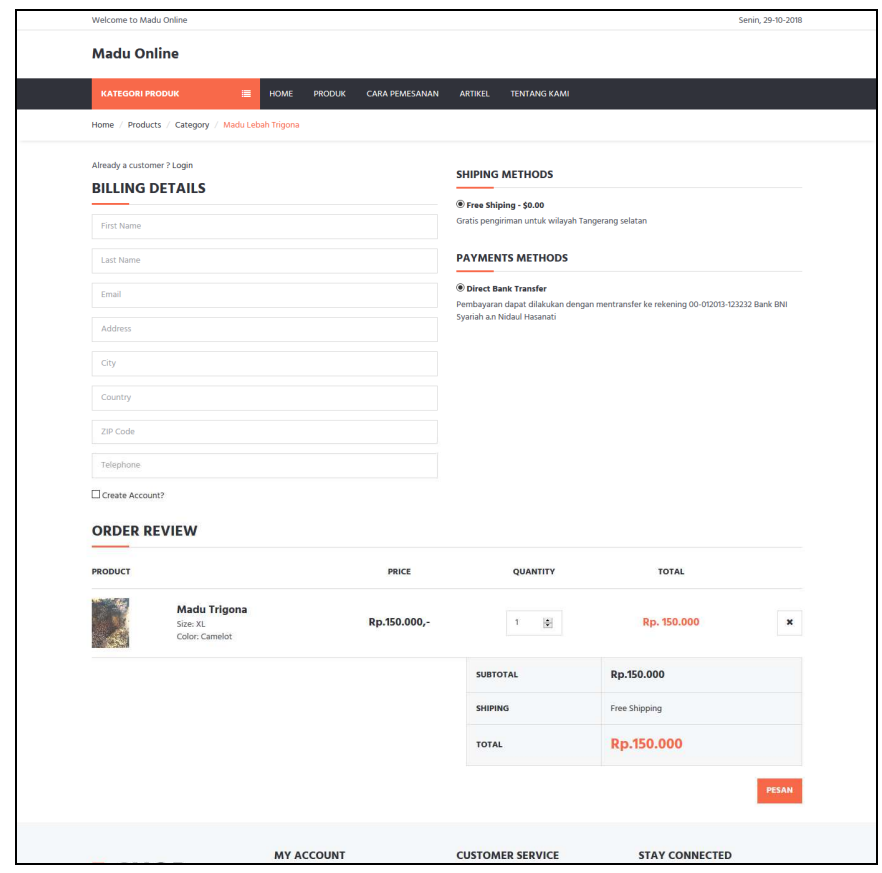

Figure 6. Order and Billing Transaction Interface

\section{Conclusion}

The e-commerce system built can help to sell honey bee products online to all customers, also can manage the stock of products and billing transaction. Based on the results of black box testing, the e-commerce system that was built was in accordance with what was expected and could function properly.

This system is one of the channels to increase product sales competitiveness, it must still be supported by other channels. to market this product. And if this e-commerce website wants to be implemented, it must still be supported by other promotional facilities such as advertisements to introduce online shop brands, so that customers are aware of the ecommerce system brand, and want to visit this website.

Acknowledgment. This paper in conjuction with International Conference on Science and Technology, Bangunan Pejabat Timbalan Naib Canselir (Penyelidikan dan Inovasi), Universiti Putra Malaya Selangor, Malaysia.

\section{References}

[1] Medah, M. (2009). E-commerce Sebagai Pendukung Pemasaran Perusahaan. Partner, 16(1), 74-81. 
[2] Rao Pasupuleti, Krishnan Kumara Tevan, Salleh Naguib, Gan Siew Hua. Biological and Therapeutic effect of Honey produced by Honey Bees and Stingless Bees. Revista Brasileira de Farmacognosia.Volume 26.Issue 5, pp. 657-664, 2016.

[3] Novandra, Alex; Widnyana, I. M. Peluang pasar produk perlebahan Indonesia. Departemen Kehutanan: Balai Peneltian Teknologi Hasil Hutan Bukan Kayu, 2013.

[4] Saepudin Rustam. Identifikasi Permasalahan Perlebahan sebagai Dasar Pengembangan Usaha Madu di Propinsi Bengkulu. Journal Sain Pertanian Indonesia. Vol.10.No.1. Hal 51-52.ISSN 19783000, 2015.

[5] Produksi Madu Indonesia 5.000 Ton Setahun [Online]. Available at https://www.antaranews.com/berita/458883/produksi-madu-indonesia-5000-ton-setahun. 2014

[6] Berem Risper M.. Economic Analysis of Honey Production and Marketing in Bringo County, Kenya, An Aplication of the Instittutional Analysys And Development Framework. Journal Of atural Science. Risearch. 2-ISSN 2225-0921.Vol.5. No.10. pp 34-41, 2015.

[7] Heilemariam Atsbaha dan Tolemariam Taye. 2017. Assesment of honey Marketing System and Its Value Chain In Trhee Selected Woredas Of Tigray Region, Ethiopia. Journal Of marketing and Consumer Research. ISSN 2422-8451 An International Peer-Reviewed Journal.Vol.35.Hal 37-47 [8] Zaric Vlade, Vasiljevic Zorica, Nedie Nebojsa, Petkovic Danijela. 2012. The Marketing Strategis Of Serbian Honey Producers. Agroinform Publishing House, Budapest. Hal 27-31

[9] Saner Gamze, Engindeniz Sait, Yercan Murat, Karaturhan Buket. 2007.Alternative Marketing Strategies For Honey and Other Bee Product In Turkey. Journal Agriculture and Food Information. Do:10.1080/10496500802083690.Hal 64-74

[10] Rachmawati Rina, 2011. Peranan Bauran Pemasaran (Marketing Mix) terhadap Peningkatan Penjualan (Sebuah Kajian terhadap Bisnis Restoran) Jurnal Kompetensi Teknik Vol. 2, No. 2, Mei 2011

[11] Sefudin Akhmad. Redefinisi Bauran Pemasaran (Marketing Mix)“4p” Ke "4c"(Studi Kasus Pada Universitas Indraprasta PGRI). JABE (Journal of Applied Business and Economic), 2017, 1.1: 17-23.

[12] Meier, Andreas, and Henrik Stormer. eBusiness \& eCommerce: managing the digital value chain. Springer Science \& Business Media, 2009.

[13] Budiarto, E. 2002. Biostatistika untuk Kedokteran dan Kesehatan Masyarakat. Jakarta: EGC.

[14] Sugiyono. 2006. Statistik Penelitian. Bandung: Alfabeta.

[15] Cortopassi-Laurino, M., Imperatriz-Fonseca, V. L., Roubik, D. W., Dollin, A., Heard, T., Aguilar, I. B., Venturieri, G. C., Eardley, C., \& Neto, P. N. 2006. Global Meliponiculture: challenges and opportunities. Apidologie, 37, 1-18. 